\title{
The relationship between internal marketing and employee job satisfaction: A study from retail shops in Bangladesh
}

\author{
Md. Atiqur Rahman Sarker \\ Department of Business Administration \\ East West University, Dhaka, Bangladesh \\ Dewan Mehrab Ashrafi \\ Faculty of Communication \& Environment \\ Rhine-Waal University of Applied Sciences, Germany
}

\section{Key Words}

Internal Marketing, Job Satisfaction, Customer satisfaction, and Organizational performance.

\begin{abstract}
A Retail store is now a prevalent concept in Bangladesh offering a wide range of necessity goods for household and daily living. Within the last one decade, superstores have developed positive perceptions among customer and this is the attractive business to many investors. As retail shop business is based on service sector, customer satisfaction and service delivery are keys to the success where having satisfied employees are essential. Hence, to achieve sustainable organizational development and higher organizational performance in this competitive market, the need of having a special emphasis on effective internal marketing practice is worth mentioning. Viewing employees as an internal customer is essential and vital in internal marketing that contributes to job satisfaction.

This paper aims to analyze the relationship between internal marketing factors and employee job satisfaction in the retail sector of Bangladesh. The essential assumptions in the research are internal marketing components namely training and development, organizational support, pay and rewards, and retention policy influence job satisfaction. A multiple regression analysis was used as an efficacious method to test the effect of internal marketing practices on employee's job satisfaction. The adjusted $R^{2}$ is 751 which suggests that the four internal marketing elements explain close to 75.1 percent of the variance for the dimension of employee's job satisfaction.

The results of the multiple regression analysis elucidate that there is variation in the effect of internal marketing factors on job satisfaction. So, it can be deduced that the stronger the internal marketing practice; the better will be the level of employee satisfaction. Organization should treat employees as an internal customer and give them opportunities for developing themselves. The company should ensure that they have the promotion opportunity and frequent feedback along with ensuring a healthy working environment. A company should induce financial rewards by providing bonus, commissions etc. to increase the satisfaction level. Since internal marketing practices act as a precursor to higher organizational performance and job satisfaction, special attention has been given in this paper to focus the importance of internal marketing practices.
\end{abstract}

Corresponding author: Md. Atiqur Rahman Sarker

Email addresses for corresponding author: mars@ewubd.edu

First submission received: $7^{\text {th }}$ August 2017

Revised submission received: $8^{\text {th }}$ November 2017

Accepted: $5^{\text {th }}$ December 2017

\section{Introduction}

Business organizations need to attract and retain customers as well as employees to ensure a sustainable competitive advantage (Schultz, 2002; Shabnam and Sarker, 2012). To achieve this objective, retail super shops must focus on their efforts for developing and sustaining an organizational culture that emphasize on employee satisfaction through effective internal marketing practices. Employee plays a central role in attracting, building and maintaining relationships with customers (Lings and Greenley, 2005; Schultz, 2002). The recognition of the central role of employees has given rise to "internal marketing" 
programs strongly oriented to employee development. It was revealed that internal marketing orientation is a significant variable in employee job satisfaction, and therefore, the internal market can be effective by practicing it properly. According to Melten et.al. (2005), "the internal support concept is grounded in the view of the service-contact workers as consumers of internal resources generated and supplied by others within the firm". The implied assumption is that satisfied employees will perform their jobs better which has positive impact on customer satisfaction (Berry, 1981; Chi, et.al., 2016). Hence, satisfied internal customers will also be loyal and more unlikely to change their jobs which results in decreased turnover.

Job satisfaction is of great significance for employees to remain happy and also deliver their level best. Satisfied employees tend to be loyal towards their organization and stick to it even in the worst time. Ivancevich, et. al. (1997) mentioned that job satisfaction is the state a worker has of a feeling how well he or she is in an organization. Satisfied employees hardly think of leaving their current jobs and it is vital to ensure higher revenues for any particular organization. Farzad (2007) asserts that the fundamental tool for achieving employee satisfaction is considering employees as customers. In order to achieve organizational expectation, the employees will be searching for improvement and motivational methods such as motivation system, training and job design, etc to increase their organizational and individual performance (Ahmed,et.at.,2003; Tsai and Tang, 2008; Isik and Altunoglu, 2016).

One of the main goals of service sectors is to achieve higher level of customer satisfaction and often employees act as a precursor to customer satisfaction. The target of satisfied customer can be achieved if the employees are satisfied through internal marketing (Ismai and Sheriff, 2017; Kotler, 2000; Pitt, et.al., 1999; Schultz, 2002). This paper aims to elucidate the relationship between internal marketing factors and job satisfaction in the retail sector. The specific objectives are as follows.

- To determine the factors that constitutes internal marketing.

- To determine the demographic and socio-economic profile of employees in urban retail sector.

- To examine if internal marketing orientation affects job satisfaction.

- To help formulating appropriate internal marketing strategies to enhance satisfaction of retail super shop employees.

\section{Theoretical background of internal marketing and its importance:}

The term internal marketing appears to have been first used by Berry et al. (1976) and later by George (1977) and Thompson et al. (1978) and Murray (1979). Internal marketing orientation has begun as a method to motivate and satisfy employees, developed through a customer orientation phase (Ali, 2016; Ahmed and Rafiq, 2000). The concept of internal marketing has evolved from the original conceptualization of employee satisfaction and motivation by treating employees as customers and jobs as products for improving service quality (Azzam, 2016; Berry, 1981; Sasser and Arbeit, 1976). Stauss and Hoffman (2000) defined internal marketing as "The planned use of communication actions to systematically influence the knowledge, attitudes and behaviors of current employees". Internal marketing is defined as treating both employees and customers with equal importance through proactive programs in order to achieve the objectives of the organization (Braimah, 2016; Woodruffe, 1995).

The main concept of internal marketing is to make the employees as important as the external customers by treating them as internal customers (Ali, 2016; Kanyurhi and Akonkwa, 2016; Grönroos,1981). Internal marketing orientation is an important concept where organizations apply marketing tools to attract and retain the best employees, which will affect business performance. There are many dimensions of internal marketing. According to Rajvalakshmi and Kameswari (2012), internal marketing dimensions like training and skill development activities, work environment, superior support, coworker support and recognition have a significant impact on the satisfaction level of employees. On the other hand, Hogg, Carter and Dunne (1998), mentioned that dimensions of internal marketing measurement are: communication, staff training; appraisal and feedback; and customer consciousness. Ahmed and Rafiq (2000) classified these dimensions into strategic rewards; internal communications; training and development; organizational structure; senior leadership; physical environment; staffing; selection and succession; inter-functional coordination; incentive systems; empowerment; and operational process changes. Tsai and Tang (2008) identify the key elements of internal marketing including service training programs, performance incentives, and vision for service excellence. The dimensions of internal 
marketing measurement as discussed by Berry et al. (1976) involve actions such as employee attraction and selection, employee socialization, empowerment, participation in decision making and establishment of accurate and open information between employees and management.

Internal marketing acts as a precursor to service excellence as Greene et al. (1994) suggest that internal marketing orientation is the key to excellent service and success of external marketing. However, literatures have depicted that, internal market orientation has an impact on employee's roles and responsibilities. Satisfied customer can be achieved if the employees are satisfied (Ali, 2016; Kukreja, 2017; Kotler, 2000; Pitt, et.al., 1999; Schultz, 2002) and satisfying employees can be easily achieved through internal marketing. In addition to that, the importance of internal marketing lies in motivating the employees and encouraging them to offer super services to customers who will improve the customer satisfaction of the company's services (Kukreja, 2017; Lings and Greenly, 2005). According to Kotler (2000), internal marketing should be as a priority before external marketing. Internal marketing starts with the organization recruiting the right people in the position to reach the point where these employees are satisfied and willing to do their job and accomplish customer satisfaction. Internal marketing is also significant for business performance in retail sector since profit maximization mostly depends on customer satisfaction in this sector. Therefore, this study reveals the direct relationship of internal marketing and employee job satisfaction in retail sector of Bangladesh which has not be covered yet by another researchers.

\section{Job satisfaction and its importance}

Job satisfaction is pivotal to the growth of any organization. Lawler (1973) defined job satisfaction as a person's affective reaction to his total work role. Kallerberg (1977) stated that job satisfaction refers to an overall affective orientation on the part of individuals toward work roles which they are presently occupying. According to Ali (2016), one of the most frequently studied concepts in organizational sciences is job satisfaction. According to Yildiz (2016) and Zeffane (1994), job satisfaction is one of the most widely debated topics in the areas of organizational behavior and human resource management. Ali (2016), for instance, defined job satisfaction as the pleasurable emotional state resulting from the appraisal of one's job as achieving or facilitating the achievement of one's job value. However, internal marketing practices can result in a positive as well as rewarding experience which affects employees job satisfaction as Suzuki et al. (2006) refers to job satisfaction as a joyful or positive emotional state regarding work or the work experience. According to Shimizu et al, (2005), job satisfaction is the level of satisfaction achieved through the job itself, through facets such as sense of achievement, growth, self-esteem, independence, and sense of control. According to Herzberg (1966), the leading dissatisfactions are Company policy, Supervision, Relationship with boss, Work conditions, Salary, Relationship with peers. The leading to satisfaction of a job are Achievement, Recognition, Work itself, Responsibility, Advancement, and Growth and so on. It is concluded that the predictors of employee satisfaction namely, reward and recognition (including salary and benefits), career advancement, promotional opportunities, work environment (including personal safety), leadership, relationship with supervisor or manager, relationship with co-worker, stress and pressure, role clarity and job fit, empowerment, training and development, feedback, decentralized decision making, sharing of knowledge and information and organizational culture (Ali, 2016, Azzam, 2016,Ahmad Wasay and Malik, 2012; Gu and Sio, 2009; Halepota and Shah, 2011; Kanyurhi and Akonkwa,2016; Schon,2007; Rad and Yarmohammadian, 2006; Roos, 2005).

Job satisfaction is complex phenomenon with multi facets. It is influenced by the factors like salary, working environment, autonomy, communication, and organizational commitment. Job satisfaction is the key ingredient that leads to recognition, income, promotion, and the achievement of other goals that lead to a feeling of fulfillment (Azzam, 2016; Kukreja, 2017; Kaliski, 2007; Yildiz, 2016). However, employee satisfaction leads to customer satisfaction. One of the main goals of service sectors is to achieve higher level of customer satisfaction and often employees act as a precursor to customer satisfaction. Satisfied customer can be achieved if the employees are satisfied (Kukreja, 2017; Kotler, 2000; Pitt, et.al., 1999; Schultz, 2002). Satisfying employees can be easily achieved through internal marketing. However, various literatures show that selection and appointment, training and development, communication, compensation, retention policy as well as organizational support affect job satisfaction of 
employees. Specific focus is given on internal marketing and its impact on retail employee's job satisfaction in Bangladesh which is completely new in this study.

\section{Internal marketing and employee job satisfaction:}

The relationship between internal marketing and job satisfaction had been the concern of many researchers (Azzam, 2016; Braimah, 2016; Kukreja, 2017; Rajyalakshmi and Kameswari, 2009). If an organization implements internal marketing then the organization is upgrading job satisfaction for employees which will lead definitely to enhancing the performance of the organization (Ali, 2016; Ahmed, at.al., 2003; Conduit and Mavondo, 2001; Tansuhaj et al. 1991). Rajvalakshmi and Kameswari (2012) found that training and skill development activities, work environment, superior support, coworker support and recognition had a significant impact on the satisfaction level of employees. On the other hand, Hogg, Carter and Dunne (1998), mentioned about communication, staff training; appraisal and feedback; and customer consciousness as dimensions of internal marketing measurement. Likewise, research has found that reward and recognition, career advancement, promotional opportunities, work environment, leadership, relationship with supervisor or manager, relationship with co-worker, stress and pressure, role clarity and person job fit, empowerment, training and development, feedback, decentralized decision making, sharing of knowledge and information and organizational culture are crucial to job satisfaction (Ali, 2016; Ahmad,et.al., 2012; Braimah, 2016; Halepota and Shah, 2011). So, it can be deduced that internal marketing has a strong correlation with employee job satisfaction.

Furthermore, job satisfaction is influenced by the factors like salary, working environment, autonomy, communication, and organizational commitment; which are also crucial elements of internal marketing (Braimah, 2016; Chi, et.al. 2016; Isik and Altunoglu, 2016; Kanyurhi and Akonkwa, 2016; Lane, et.al. 2010; Vidal, et.al. 2007). An empirical study conducted on the impact of internal marketing factors on job motivation and job satisfaction in the retail stores revealed that the working conditions and hours, hygiene and sanitation, rest rooms, support from superior, and attitude of colleagues have highest influence on job satisfaction and motivation (Rajyalakshmi and Kameswari, 2012). The findings revealed a positive relationship between the internal marketing practices and employee job satisfaction. Many of the studies highlighted the relation between internal marketing and job satisfaction. The factors of internal marketing like pay, coworker support, supervisors, working conditions, job security, promotional aspects, nature of work, employee selection, employee training and development, work design, employee rewards and compensation, fairness, recognition, flexibility, feedback, quality of service, employee development, vision of the organization, strategic reward, internal communication and senior leadership have been concentrated upon by different authors over the years. Based on the literature, the present study identified five dimensions of internal marketing factors: selection and appointment (staffing), training and development, organizational support, pay and rewards and retention policy. These dimensions are studied within the retail super shop employees, to identify their relation to job satisfaction. The established relationship from the literature between the various internal marketing dimensions and employee job satisfaction is shown in figure 1 below.

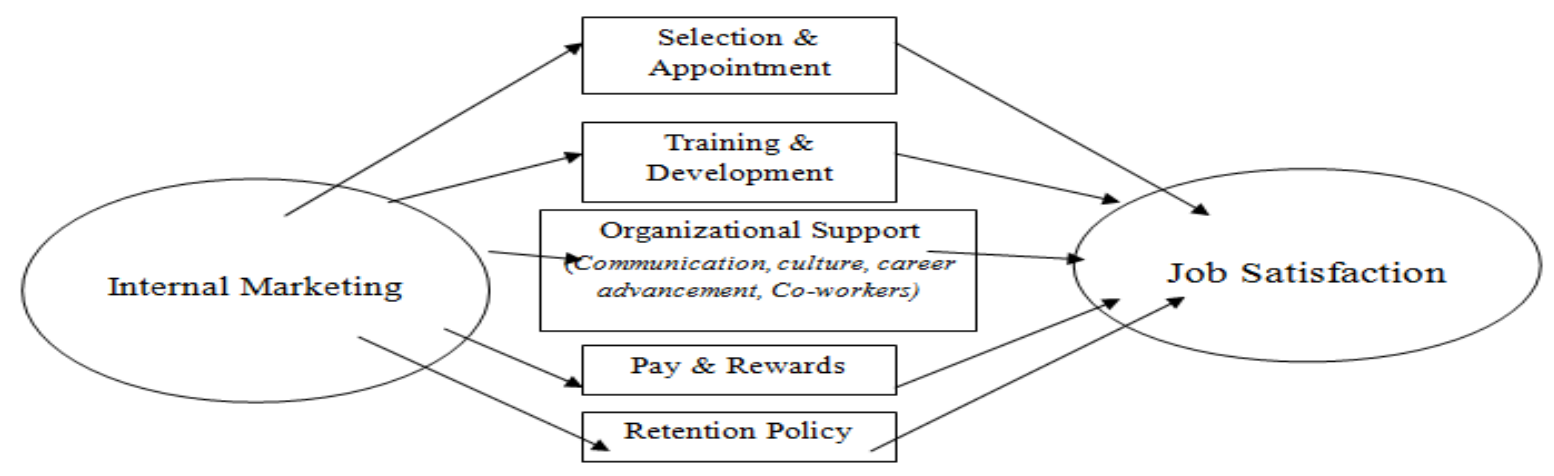

Figure-1: Model of internal marketing and employee job satisfaction. 


\section{Research Hypotheses:}

Based on the research model in figure-1 and existing literature review, the following hypotheses are developed to test the relationship between internal marketing and employee job satisfaction specifically in retail sector of Bangladesh. The test measures particular five components of internal marketing and their relationship with job satisfaction.

HI: Internal marketing has positive significant effect on job satisfaction.

H1.1: Selection and appointment have positive effect on job satisfaction.

H1.2: Training and development have positive effect on job satisfaction.

H1.3: Organizational support has positive effect on job satisfaction.

H1.4: Pay and rewards has positive effect on job satisfaction.

H1.5: Retention policy has positive effect on job satisfaction.

\section{Retail Business in Bangladesh:}

Retail business in Dhaka city of Bangladesh is playing a significant role in community life. It is offering a good number of employments at present, and this sector is booming due to huge business demand. According to Siddiqui, et.al. (2006), there are five categories of retail shops in Bangladesh; (1) Roadside Shops (Traditional \& Unstructured), (2) Municipal Corporation Markets (Traditional $\mathcal{E}$ Unstructured), (3) Convenience Stores (Traditional \& Unstructured), (4) Supermarkets (Organized and Structured), (5) Superstores (Organized and Structured). Almost 20,000 products are being offered by these superstores with prime focus on food items including a large variety of fish, meat, vegetables, fruits, bakery, dairy and grocery items (Munni, 2010). Furthermore, retail shops in Bangladesh also provide household, personal care and miscellaneous products (Siddiqui, et.al. 2006; Munni 2010). According to BSOA (Bangladesh Supermarket Owner Association), retail chain stores in Bangladesh get 15\% to 20\% annual growth in sales, and they claim that the annual turnover of the superstores now stands at the BDT 15 billion approximately (Munni M, 2010). The present retail organizations which are performing as organized retailing in Bangladesh are going through myriad challenges in procuring, maintaining and retaining good employees (Kashem, 2012; Sarker and Afroze, 2015; Shamsher and Hossain, 2012). Many of the employees often complain of not having financial rewards or incentives; they call themselves underpaid and one of the consequences of this can be called as lack of motivation (Sarker and Afroze, 2015; Shamsher and Hossain, 2012). Some employees behave like superior, and they often do not cooperate with customers (Sarker and Afroze, 2015). Working in a team is an important quality that every single employee should possess, but some of the organizations are doing an extra ordinary job while others are performing below average (Kashem, 2012). Pay for performance is not practiced well in most of the cases. Therefore, improving employee's job satisfaction is a serious concern in recent time. This paper has focused the role of internal marketing in satisfying internal customers (employees) that ultimately makes the external customer happy with higher profitability in retail sector of Bangladesh.

\section{Methodology:}

Primary data were obtained through a structured questionnaire survey where the questionnaire is developed based on published literature on internal marketing and job satisfaction by different authors. The target population of this study was employees of retail shops in Dhaka city of Bangladesh. Respondents were selected randomly based on convenient sampling. Survey data had been collected between November, 2016 and April, 2017. 250 employees from the retail sector responded to the survey and all participants have been kept anonymous. In the first part of the survey questionnaire, there were questions about the demographic profile of employees with multiple choice questions about their gender, age, average monthly income and family size. In addition to that, factors influencing employee satisfaction were identified through secondary data analysis from relevant journals and books. For instance, independent variables were identified as training opportunities, verbal appreciation, promotion opportunity, feedback of supervisor, work relationship, compensation package, existing salary structure, financial and non-financial rewards, organizational policies etc. from the literature of different published research journals. The statistical software used for the analysis of questionnaires was SPSS. The data of all the independent variables were tested first using Cronbach's alpha reliability test to assess reliability. Multiple regression analysis has been done to find out if the independent variables have a significant 
relationship with the dependent variable. The statistical significance difference targeted was .05 alpha levels which are prevalent in most research (Cooper and Schindler, 2006).

\section{Findings}

In the survey questionnaire, all constructs were evaluated using five-point Likert scale. Random office personnel from retail sector were surveyed who fell in appropriate criteria. Among the 250 respondents, $77 \%$ were male respondents and $23 \%$ were female from different age groups and job positions. Among them, 61\% were from age less than 25 years, 34\% were from age between 26 and 35 years, $5 \%$ were from age between 36 and 45 years. $32 \%$ of the respondent was from managerial position, $56 \%$ were from sales unit and $12 \%$ belonged to cash in charge and accountant. There were also differences among the respondent's average monthly income. 59\% respondents had monthly income below BDT 15000, 33\% people had income between BDT 15000 and BDT 25000, $6 \%$ of them had income between BDT 25000 and BDT 35000 and only 2\% had the income of more than BDT 45000 (USD 580). The number of family members also varied. For instance, $27 \%$ of the employees have a family of $1-3$ members, $65 \%$ have 5-6 family members, and $8 \%$ of the employees have a family of more than 6 members.

Only $11 \%$ of the employees agreed and $2 \%$ strongly agreed that their salary encourages them to work with full dedication while 59\% of the respondents were not happy with their salary structure. However, only $23 \%$ of the high achieving employees get financial and non-financial reward which is quite alarming. $53 \%$ of the respondents were not satisfied with the organization policy. At the same time, $58 \%$ employees believe that their organization will replace them if they find new employees for the same position to whom they will have to make lesser payments, which is undesirable. Contrarily, 59\% of retail employees are satisfied with their supervisors and $72 \%$ of the employees get the opportunity to ameliorate their working skills through participating in myriad training and development programs.

\subsection{Descriptive statistics analysis}

Table (1) in the appendix elucidates that employees of retail sector perceived organizational support (with the highest mean scores, i.e. $\mathrm{M}=3.54$ ) to be the most dominant of internal marketing practices followed by training and development $(M=3.38)$, retention policy $(M=2.96)$, and pay \& rewards $(M=2.34)$ respectively. However, employees of retail sector rated job satisfaction with a mean of 2.91.

\subsection{Multiple Regression Analysis}

The essential assumptions in the research are internal marketing components namely training and development, organizational support, pay and rewards, and retention policy influence job satisfaction. A multiple regression analysis was used as an efficacious method to test the effect of internal marketing practices on employee's job satisfaction. According to Table 2 shown below, the adjusted $R^{2}$ is .751 which suggests that the four internal marketing elements explain close to 75.1 percent of the variance for the dimension of employee's job satisfaction.

\begin{tabular}{|lcccc|}
\hline $\begin{array}{l}\text { Model } \\
\text { Error of the Estimate }\end{array}$ & R Square & Adjusted R Square & Std. \\
1 & $870^{\mathrm{a}}$ & .758 & & \\
.36382 & & & .751 & \\
\hline
\end{tabular}

Table 2: Predictors: (Constant), Mean Retention policy, Mean Training \& development, Mean Organizational support, Mean Pay\& rewards

Table 3 shows that pay and rewards (56.2\%) and organizational support (23.7\%) appears to show the greatest impact on job satisfaction. In addition, the impact of training and development, organizational support, pay and rewards, and retention policy on job satisfaction would vary according to the demographic profile. The results of the multiple regression analysis elucidate that there is variation in the effect of internal marketing factors on job satisfaction. 


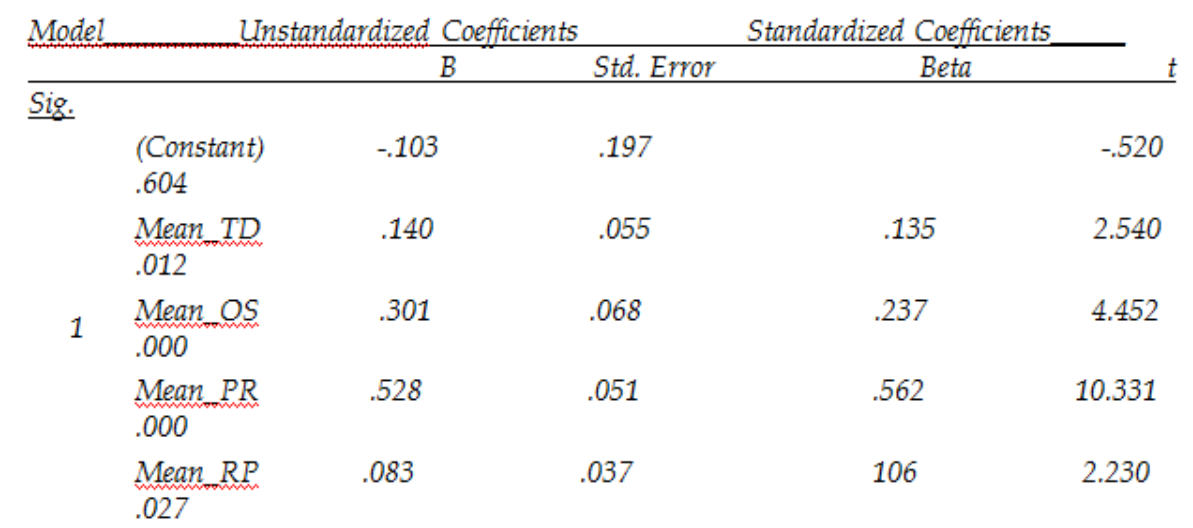

Table 3 : a. Dependent Variable: Mean Job Satisfaction

Where,

TD $=$ Training $\&$ Development

OS=Organizational Support

$P R=$ Payment $\&$ Rewards

$R P=$ Retention Policy

\section{Discussion}

HI: Internal marketing has positive significant effect on job satisfaction:

One of the research findings that can be concluded from the statistics provided in the findings part is that there is a significant relationship between internal marketing and employee job satisfaction. From the analysis, it is found that there is a significant relationship between internal marketing and employee job satisfaction $(p=.000)$. The result is consistent with the findings of Rajvalakshmi and Kameswari (2012) which depicts the variables such as training and development, work environment, superior support, coworker support and recognition had a significant impact on the satisfaction level of employees. However, the results also show that, factors like salary, working environment, autonomy, communication, and organizational commitment influence the level of job satisfaction identified by (Lane, et.al., 2010; Vidal, et.al., 2007). So, it can be deduced that the stronger the internal marketing practice; the better will be the level of employee satisfaction. Organization should treat employees as an internal customer and give them opportunities for developing themselves. The company should ensure that they have the promotion opportunity. They should provide frequent feedback along with ensuring a healthy working environment. A company should induce financial rewards by providing bonus, commissions etc. to increase the satisfaction level. However, they should maintain a good relationship with their internal customer as well.

H1.1: Training and development have positive effect on job satisfaction.

Training and development are viewed to be one the most crucial and pivotal factors $(p=.012)$ related to the job satisfaction of the employees in the retail sector. This research has empirically revealed a positive relationship between training - development and job satisfaction as influential factors on the adoption of internal marketing concept (Tsai and Tang, 2008; Rajvalakshmi and Kameswari, 2012). The result is also consistent with the findings of Khan et. al., (2011) which showed training and development is one of the important factors that had a positive and significant dimensionality to internal service quality. Organizations should provide more opportunities to develop their employees and should consider the skill expansion as an investment. In addition to that, an organization should encourage high flexibility regarding diverse training needs of employees.

H1.2 Organizational support has positive effect on job satisfaction.

From the analysis, it is found that there is a significant relationship between organizational support and employee job satisfaction $(\mathrm{p}=.000)$. The more the organizational support, the more will be their satisfaction. It is often said that people leave managers; not companies. An amiable supervisorsubordinate relationship has impact on job satisfaction. Moreover, Smith et. al., (1969) opined that the most accepted and common facets of job satisfaction are the satisfactions with pay, promotion 
opportunities, coworkers, supervision, and the work itself. Organizations should give their employees more verbal recognition as it motivates them to work properly. Supervisors should also provide them frequent feedbacks to increase their performance. However, companies should ensure a healthy work relationship and environment as well. In addition to that, supervisors should communicate with them more openly and should respect their opinions too.

H1.3: Pay and rewards have positive effect on job satisfaction.

The results points out a significant relationship between pay and rewards and employee job satisfaction $(p=.000)$ which demonstrates job satisfaction is influenced by the factors like salary, working environment, communication, autonomy and organizational commitment; which are also crucial elements of internal marketing (Lane, et.al., 2010; Vidal, et.al., 2007). The results also indicate that rewards lead to higher recognition of achievement and increase employee satisfaction. So, if organizations increase the opportunities to get rewards, the employees will more likely to be satisfied. Organizations should introduce such compensation package so that it encourages the employees to work with full dedication. If they feel that payment they are receiving is higher than the others working in the same positions, they will more likely to be satisfied. Moreover, organizations should provide more financial rewards along with non-financial benefits to boost up employees motivation.

H1.4: Retention policy has positive effect on job satisfaction.

There is a significant relationship between retention policy and employee job satisfaction. From the analysis, it is found that there is a significant relationship between retention policy and employee job satisfaction $(p=.027)$. Prior research has empirically revealed a positive relationship between retention policy and job satisfaction (Suzuki et. al, 2006; Rajyalakshmi and Kameswari, 2009). These results indicate that the retention policy is a vital element to retain the employees. Thus, this will have a significant impact on the employee job satisfaction. If employees feel a sense of belongingness, they will more likely to be satisfied. Organizations should make better relationships with their employees and they are company's internal customer. Management should not neglect their point of views and should pay the salary that they deserve. Thus it ensures job satisfaction of the employees.

\section{Conclusion}

The prime purpose of the research was to analyze the relationship between internal marketing practices and employee job satisfaction. This research has fulfilled the objectives as a mentioned earlier above. The first objective was to analyze the relationship between internal marketing practices and job satisfaction which revealed a positive relationship. This proves that internal market orientation and employee job satisfaction was connected with each other. The second objective is to identify the relationship between training and development and employee's job satisfaction. Finding dictates that there was a significant relationship. The third objective was to find out the relationship between organizational support and employee's job satisfaction. The finding reveals that there is positive correlation between organizational support and employee job satisfaction. Another objective was to examine the relationship between pay and rewards and employee's job satisfaction. The findings depicted that there is a positive relationship between them. The regression result shows that the pay and rewards are the most important factor to evaluate the employee's job satisfaction in the retail sector in Bangladesh. In conclusion, this research has successfully attended the four research objectives and proved that internal marketing is positively related with employee job satisfaction.

\section{Limitation and scope of the study}

This research has revealed that internal marketing is connected with employee job satisfaction in retail sector of Bangladesh. However, this result is only valid for employees in the organizations understudy. Extensive study of all organizations in retail sector of Bangladesh was not covered due to inconvenience of collecting data and conducting interview of the respondents. This study will assist future research to examine the relationship between the internal marketing practices and employee job satisfaction in other organizations and sectors. It will also bring attention of the policy makers and practitioners to motivate employees of retail sectors in particular. 


\section{References}

Ahmad, M.B., Wasay, E. Malik, S.U (2012). “Impact of employee motivation on customer satisfaction: a study of airline industry in Pakistan". Interdisciplinary Journal of Contemporary Research in Business, 4(6): 531-539

Ahmed, P.K. And Rafiq, M. (2000). "Advancing in the internal marketing concept: definition, synthesis and extension". Journal of Services Marketing, 14 (6): 449-462.

Ahmed, P.K., Rafiq, M. and Saad, N.M. (2003). "Internal marketing and the mediating role of organizational competencies", European Journal of Marketing, 37(9): 1221-41.

Ali, Sally. (2016). "Determine the effect of relationship between internal marketing variables and employee's job satisfaction and organizational commitment: Case study of Arab Academy for Science, Technology and Maritime Transport". The Business and Management Review. 7(2):124-133.

Azzam, Zakaria (2016)."Internal marketing as a tool for maintaining high quality services provided by services firms: A case of hospitality industry in Jordan". International Journal of Economics, Commerce and Management. 4(4):380-393.

Berry LL. (1981). “The employee as a customer". Journal of Retail Banking. 3 (2): 33-44.)

Berry, L.L., Hensel, J.S. and Burke, M.C. (1976). "Improving retailer capability for effective consumerism response". Journal of Retailing, 52 (3) : 3-14.

Braimah, Mahama. (2016)."Internal marketing and employee commitment in the hospitality industry". African Journal of Hospitality, Tourism and Leisure. 5(2). ISSN:2223-814X

Chi,H., Yeh,H., Liou, J. (2016). "How Internal Marketing Mediates the Relationship between Teacher's Organizational Commitment and Job satisfaction". Journal of Education \& social policy. 3(1):56-69.

Conduit, J. and Mavondo, F. T. (2001). "How critical is internal customer orientation to market orientation?" Journal of Business Research, 51(1):11-24.

Cooper, D. R., and Schindler, P. S. (2006). Business Research Methods. $9^{\text {th }}$ edition. USA: McGraw-Hill

Farzad, Atousa. (2007)."The effect of internal marketing on organizational commitment". Retrieved on 9 March, 2016 from http:/ / epubl.luth.se/1653-0187/2007/053/LTU-PB- EX-07053-SE.pdf

George, W. R. (1977). “The retailing of services: a challenging future”. Journal of Retailing. 53, 85-98.

Greene, W. E., Walls, G. D. and Scbrest, L. J. (1994). "Internal marketing: The key to external marketing success". Journal of Services Marketing, 8 (4): 5-13.

Grönroos, C. (1981). "Internal marketing an integral part of marketing theory". In Marketing of Services. Edited by Donnelly JH Jr., George WR. Chicago: American Marketing Association. 236-238.

$\mathrm{Gu}, \mathrm{Z}$. and Siu, R.C.S. (2009). "Drivers of job satisfaction as related to work performance in Macao casino hotels". International Journal of Contemporary Hospitality Management, 21(5):561:578

Halepota, J.A. and Shah, N. (2011). "An empirical investigation of organizational antecedents on employee job satisfaction in a developing country". Transforming Government: People, Process and Policy, 5(3):280-294.

Herzberg, F. (1966). Work and the nature of man. New York: The Word Publishing Company.

Hogg, G., Carter, S. and Dunne, A. (1998). "Investing in people: internal marketing and corporate culture", Journal of Marketing Management, 14: 879-895.

Isik, Derya and Altunoglu,A. (2016). "The Effects of Internal Marketing on Some Job Attitudes: A Study in Private Hospital in Turkey". Journal of Business research Turk. 8(2):1-17

Ismail,W. and Sheriff, N.M. (2017). "The effect of internal marketing on organizational commitment: An empirical study in banking sector in Yemen". Polish Journal of Mnagement Studies. 15(1):88-98.

Ivancevich, J., Olelans, M., and Matterson, M. (1997). Organizational Behavior and Management. Sydney: Irwin

Kashem, M. A. (2012). “The Bangladeshi Consumer Behavior and Attitude toward Superstores". European Journal of Business and Management, 4 (8): 85-94.

Kaliski, B.S. (2007). Encyclopedia of Business and Finance. $2^{\text {nd }}$ edition. Detroit: Thompson. 446

Kalleberg, A. (1977). "Work Values and Job Rewards: A Theory of Job Satisfaction". American Sociological Review. 42,: 124-143. 
Kanyurhi, Eddy and Akonkwa, Deogratias (2016). "Internal marketing, employee job satisfaction, and perceived organizational performance in microfinance institutions". International Journal of Bank Marketing. 34(5):773-796.

Khan, A., Ur-Rehman, A., Safwan1., and Ashfaq, A. (2011). “Modeling link between internal service quality in human resources management and employees retention: A case of Pakistani privatized and public sector banks". African Journal of Business Management, 5 (3):949-959.

Kotler, P. (2000). Marketing Management. Millennium Edition. New Jersey: Prentice Hall

Kukreja, Jyoti (2017). "Internal Marketing: a prelude or an outcome of Employee Motivation". BVIMSR's Journal of Management Research. 9(1): 54-59

Lane, K.A., Esser, J., Holte, B., McCusker, M.A. (2010). “A study of nurse faculty job satisfaction in community colleges in Florida". Teach, Learn Nursing. 5:16-26.

Lawler, E. E. (1973). Motivation in work organizations. Monterey, CA: Brooks/Cole.

Lings, I.N. and Greenley, G.E. (2005). "Measuring internal market orientation". Journal of Service Research. 7 (3):290-306.

Metlen, S., Eveleth, D., and Bailey, J. J. (2005). “Management support and perceived consumer satisfaction in skilled nursing facilities". Health Services Management Research, 18(3): 198-210.

Munni, M. (2010). "Superstores eye boom time ahead", The Financial Times, April 10, 2010.

Murray, J.G. (1979). "The Importance of internal marketing". Banker's Magazine, July, 38-40.

Pitt, M., Bruwer, J., Nel,D., and Berthon, J. (1999). "A Frame work for Research in Internal Marketing and the Study of Service Quality: Some Propositions". Management Research News, 22 (7).

Rad, A., and Yarmohammadian, M. (2006). "A study of relationship between manager's leadership style and employee's job satisfaction". Leadership in Health Services, 19(2):11-23

Rajyalakshmi, Nittala and Kameswari, A. Vijaya (2009). "Internal Marketing for Customer Satisfaction in Retail Sector". The Asian Journal of research in Bankinf and Finance, 3(3): 207-220.

Rajyalakshmi, Nittala and Kameswari, A. Vijaya (2012). "Role of Internal Marketing in Job Satisfaction of Employees in State Bank of India". 9th AIMS International Conference on Management. India.

Roos, W. (2005). "The relationship between employee motivation, job satisfaction and corporate culture". Department of Psychology. Master of Science Thesis. University of South Africa.

Sarker, A.R., and Afroze, R. (2015). "Employees Perception about HRM Practices in the Selected Retail Shops in Bangladesh". British Journal of Economics, Management \& Trade, 9(4), ISSN: 2278-098X. Science Domain International, UK, July.

Sasser, E.W., and Arbeit, S.P. (1976). "Selling Jobs in the Services Sector". Business Horizons, 19 (3):61-65.

Schon, K. (2007). "Job satisfaction, Six Sigma work improvement and the interconnection between the two". Department of Business Administration and Social Sciences. Doctoral Thesis. Lulea University of Technology.

Schultz, D.L. (2002). "Study internal marketing for better impact". Marketing News, 36 (21).

Shabnam, S., and Sarker, A. R. (2012). "Impact of CSR and Internal Marketing on Employee Job Satisfaction and Organisational Commitment: A Case Study from Export-Oriented SMEs in Bangladesh". World Journal of Social Sciences, 2(7).

Shamsher, R. and Hossain, M. J. (2012). "Consumer Behavior in Retailing: A Comparative Study between Traditional and Large-scale Retailing". The Chittagong University Journal of Business studies, 21(2): 179197.

Siddiqui N, Ahmed JU, Hasan M 2006. "New Generation of Retail Management in Bangladesh - Customer Satisfaction through Value System Management". South East University Journal of Business Studies, 2 (2):1-18.

Shimizu T., Eto R., Horiguchi I., Obata Y., Feng QL., Nagata S. (2005). "Relationship between turnover and periodic health check-up data among Japanese hospital nurses: A three-year follow-up study". Journal of Occupation Health, 47(4):327-333.

Smith, P. C., Kendall, L. M., and Hulin, C. L. (1969). The measurement of satisfaction in work and retirement. Chicago: Rand McNally

Stauss, B., Hoffman, F. (2000). "Using business television”, cited in Varey, R.J., Lewis, B.R. (Eds.), Internal Marketing: Directions for Management. London : Routledg. 139-59 
Suzuki, E., Itomine, I., Kanoya, Y., Katsuki, T., Horii, S. and Sato, C. (2006). “Factors affecting rapid turnover of novice nurses in university hospitals". Journal of Occupational Health, 48 (1): 49-61

Tansuhaj, P., Randall, D., and McCullough, J. (1991). "Applying the internal marketing concept within large organizations: as applied to a Credit Union". Journal of Professional Services Marketing, 6 (2):193-202.

Thompson, T. W.; Berry, L. L.; Davidson, P. H. (1978). Banking tomorrow: managing markets through planning. New York: Van Nostrand Reinhold Company.

Tsai, Y. and Tang, T. (2008). "How to improve service quality: internal marketing as a determining factor". Total Quality Management and Business Excellence Review, 19:1117-1126.

Vidal MES, Valle RS, Aragón BMI. (2007). "Antecedents of repatriates' job satisfaction and its influence on turnover intentions: Evidence from Spanish repatriated managers". Journal of Business Research, 60: $1272-1281$.

Woodruffe, H. (1995). Services Marketing. London: Pitman

Yildiz, Suleyman. (2016). " The Effect of Internal Marketing on Organizational Citizenship Behavior of Academic Staff in Higher Educational Institutions". Universal Journal of Educational Research. 4(5):1122-1128.

Zeffane, R. (1994). "Patterns of Organisational Commitment and Perceived Management Style: A Comparison of Public and Private Sector". Human Relations, 47(8): 977-1010.

\section{Appendix}

Table 1: Mean, Standard deviation, and Reliability of study variables

\begin{tabular}{|c|c|c|c|}
\hline Construct $\&$ Item & Mean & Reliability & Standard Deviation \\
\hline Training \& Development & 3.38 & .73 & .70 \\
\hline \multicolumn{4}{|l|}{$\begin{array}{l}\text { My organization provides me enough } \\
\text { training opportunities to develop myself }\end{array}$} \\
\hline \multicolumn{4}{|l|}{$\begin{array}{l}\text { In my organization, the knowledge and skill } \\
\text { expansion of staff is taken/considered to be } \\
\text { an investment }\end{array}$} \\
\hline \multicolumn{4}{|l|}{$\begin{array}{l}\text { This organization encourages high flexibility } \\
\text { regarding the versatile/diverse training needs } \\
\text { of employees }\end{array}$} \\
\hline Organizational Support & 3.54 & .71 & .57 \\
\hline \multicolumn{4}{|l|}{$\begin{array}{l}\text { I receive verbal recognition/appreciation } \\
\text { when I achieve higher performance. }\end{array}$} \\
\hline \multicolumn{4}{|l|}{$\begin{array}{l}\text { I have opportunities to get promoted in my } \\
\text { organization }\end{array}$} \\
\hline \multicolumn{4}{|l|}{$\begin{array}{l}\text { My supervisor frequently provides me the } \\
\text { feedback regarding my work performance. }\end{array}$} \\
\hline \multicolumn{4}{|l|}{$\begin{array}{l}\text { In my organization, co-workers treat me } \\
\text { with proper respect } / \mathrm{I} \text { am satisfied with work } \\
\text { relationships with the people around me. }\end{array}$} \\
\hline \multicolumn{4}{|l|}{$\begin{array}{l}\text { Supervisors and managers communicate } \\
\text { openly with me }\end{array}$} \\
\hline \multicolumn{4}{|l|}{$\begin{array}{l}\text { I am satisfied with the given right to put } \\
\text { forward my opinions. }\end{array}$} \\
\hline Pay \& Rewards & 2.34 & .86 & .78 \\
\hline \multicolumn{4}{|l|}{$\begin{array}{l}\text { The compensation package I receive } \\
\text { encourages me to work with full dedication }\end{array}$} \\
\hline \multicolumn{4}{|l|}{$\begin{array}{l}\text { The pay I receive is higher compared to } \\
\text { others doing similar job at their companies. }\end{array}$} \\
\hline \multicolumn{4}{|l|}{$\begin{array}{l}\text { I am satisfied with the existing salary } \\
\text { structure of the company }\end{array}$} \\
\hline \multicolumn{4}{|l|}{$\begin{array}{l}\text { High achieving employees showing } \\
\text { excellent performance get financial rewards } \\
\text { (Bonus, Increases etc.) }\end{array}$} \\
\hline Retention Policy & 2.96 & .76 & .92 \\
\hline \multicolumn{4}{|l|}{$\begin{array}{l}\text { Even if the organization find employees to } \\
\text { whom they have to make lesser payment for } \\
\text { my position, they will not replace me. }\end{array}$} \\
\hline $\begin{array}{l}\text { If I decide to resign, the organization } \\
\text { management will convince me to stay }\end{array}$ & & & \\
\hline
\end{tabular}

